American Journal of Infectious Diseases 1 (1): 34-42, 2005

ISSN 1553-6203

(C) 2005 Science Publications

\title{
Evidences of Hepatitis C Virus Replication in Hepatocytes and Peripheral Blood Monocuclear Cells from Patients Negative for Viral RNA in Serum
}

\author{
${ }^{1}$ Viviana Falcón, ${ }^{1}$ Nelson Acosta-Rivero, ${ }^{4}$ Mineko Shibayama, ${ }^{4}$ Jose Luna-Munoz \\ ${ }^{4}$ Magdalena Miranda-Sanchez, ${ }^{1}$ María-C de la Rosa, ${ }^{1}$ Ivón Menéndez, ${ }^{2}$ Bienvenido Gra \\ ${ }^{1}$ Santiago Dueñas-Carrera, ${ }^{2}$ Waldo García, ${ }^{2}$ Eduardo Vilar, ${ }^{1}$ Jose Silva, ${ }^{1}$ Deliana Lopez \\ ${ }^{3}$ Maritza González-Bravo, ${ }^{1}$ Celia Fernández-Ortega, ${ }^{1}$ Dionne Casillas, ${ }^{1}$ Juan Morales \\ ${ }^{4}$ Juan Kouri and ${ }^{4}$ Victor Tsutsumi \\ ${ }^{1}$ Biomedicine Division, Center for Genetic Engineering and Biotechnology \\ P.O. Box 6162, C.P. 10600, Havana, ${ }^{2}$ Institute of Gastroenterology, C.P. 10400, Havana \\ ${ }^{3}$ National Center for Scientific Research, P.O. Box 6990, Havana \\ ${ }^{4}$ Centro de Investigación y de Estudios Avanzados (CINVESTAV-IPN), México City, México
}

\begin{abstract}
In this study, we examined the expression of hepatitis $\mathrm{C}$ virus (HCV) components in hepatocytes and peripheral blood mononuclear cells (PBMC) from patients positive for anti-HCV antibodies and negative for serum HCV-RNA. The samples obtained from 25 randomly selected patients (13 of 25 patients showed no histological evidences of chronic hepatitis and had normal serum ALAT and GGTP levels) were studied by in situ Hybridization and Immunofluorescence assays. The findings show that HCV-RNA of both positive and negative polarity was carried in the hepatocytes of more than $80 \%$ of cases. The proportion of cells expressing the negative strand (mean \pm SD, $10.25 \% \pm$ $5.56 \%)$ was lower than those expressing positive strand (mean $\pm \mathrm{SD}, 19.88 \% \pm 9.19 \%)(\mathrm{p}=0.0076$; Student's t test). In addition, reaction products suggestive of HCV core, E1 and E2 antigens within hepatocytes were also observed. Both hybridization and immunofluorescence signals were localized in the cytoplasm suggesting that this is the place of active HCV replication. On the other hand, the HCVRNA of positive polarity was detected in PBMC from 16 out of 17 samples analyzed (94\%) while the HCV-RNA of negative polarity was detected in $82 \%$ of samples investigated. Positive hybridization signals were localized in the cytoplasm of PBMC. Interestingly, 12 out of 13 patients with clinical and histological resolution of hepatitis, contain HCV-RNA in either liver or PBMC. These results provide further evidences that the intermediate replicative form of the HCV genome can persist in hepatocytes and PBMC after apparently complete resolution of chronic hepatitis $\mathrm{C}$.
\end{abstract}

Key words: HCV, liver biopsy, HCV-RNA, confocal microscopy

\section{INTRODUCTION}

Hepatitis $\mathrm{C}$ virus (HCV) infection is a major public health problem world wide. $\mathrm{HCV}$ is considered the causative agent of a wide spectrum of liver diseases, including posttransfusion non-A non-B hepatitis, chronic hepatitis and cirrhosis and primary hepatocellular carcinoma ${ }^{[1,2]}$. It is thought that the viral particle consists of a nucleocapsid containing a positive-sense, single-stranded RNA genome of approximately 9,500 nucleotides $(\mathrm{nt})^{[1]}$. The HCV nucleocapsid is surrounded by an envelope derived from host membranes into which are inserted the virally encoded glycoproteins (E1 and E2) ${ }^{[3]}$. The viral products (core, E1, E2, NS2, NS3, NS4A, NS4B, NS5A and NS5B) are processed from a 3,000-amino acid (aa) polyprotein expressed from a single open reading frame $^{[4,5]}$.
Diagnosis of $\mathrm{HCV}$ relies on either indirect serological detection of anti-HCV antibodies by enzyme-linked immunosorbent assay (ELISA) supplemented with recombinant immunoblot assay (RIBA) or directly through the detection of HCV-RNA in serum by reverse-transcription nested polymerase chain reaction (RT-PCR ${ }^{[6]}$. Although very sensitive, these assays do not allow for cell-specific localization of HCV. Other assays such as in situ hybridization (ISH), immunohistochemistry (IHC) and immunofluorescence (IF) have been used for the localization of $\mathrm{HCV}$ genome and gene products inside $\mathrm{HCV}$-infected cells ${ }^{[7-9]}$.

On the other hand, it has been reported that repeatedly negative RT-PCR for HCV-RNA in serum did not indicate absence of HCV in the liver ${ }^{[10]}$. Thus, in individuals with anti-HCV antibodies and negative for HCV-RNA in serum, it is important to assess

Corresponding Author: Dr. Viviana Falcón Cama, Center for Genetic Engineering and Biotechnology (CIGB), P.O. Box 6162, Havana 10600, Cuba, Tel: (+537)-2714764, Fax: (+537)-2714764 
intrahepatic HCV RNA status (viral levels have been demonstrated to be $10^{4}$ fold higher in liver than in serum) to determine whether they have truly spontaneously resolved past infection or have current infection ${ }^{[11,12]}$.

Application of RT-PCR and hybridization techniques has allowed the detection of HCV genomes not only in sera but also in other body fluids as well as in peripheral blood mononuclear cells $(\mathrm{PBMC})^{[13-15]}$. The extrahepatic manifestations of the presence of HCV RNA sequences led to putting forward the suggestion that they might be a reservoir of $\mathrm{HCV}$, where viral replication can take place.

In situ detection of $\mathrm{HCV}$ genome and gene products is important for the identification of cellular tropism and to obtain information about the subcellular site of viral replication. In this work, HCV components were investigated in liver and PBMC samples from patients positive for anti-HCV antibodies and negative for HCV-RNA in serum.

\section{MATERIALS AND METHODS}

Patients and samples: Patients serologically positive to third-generation $\mathrm{HCV}$ enzyme immunoassays (Tecnosuma International, Havana, Cuba) and that the anti-HCV positive sera were confirmed by Ortho HCV 2.0 ELISA (Ortho Diagnostic Systems, Rariton, NJ) were investigated after informed consent in writing was obtained. Liver needle biopsy samples were taken at the time of routine diagnostic biopsy from all patients. 25 patients were selected based upon they showed negative detection of serum HCV-RNA by RT-PCR (Amplicor HCV Amplification Kit 2.0, Roche Diagnostic Systems,Inc) on the same day of the liver biopsy. In addition, 3 chronically $\mathrm{HCV}$-infected patients were selected as controls based upon they showed positive detection of serum HCV-RNA by RT-PCR (Table 1). None were seropositive for markers of hepatitis B virus (HBV), hepatitis A virus and human immunodeficiency virus by enzyme immunoassays (Tecnosuma International, Havana, Cuba). In addition, PBMC samples were taken from 17 out of 25 selected patients and from 3 chronically HCV-infected patients on the same day of the liver biopsy. 13 of these 25 patients showed no histological evidences of chronic hepatitis and had normal serum alanine aminotransferase (ALAT) or gamma-glutamyl transpeptidase (GGTP) levels for at least six month before the biopsy was performed.

Liver needle biopsy samples were taken from 2 HCV-uninfected healthy donor livers for transplantation purpose as negative controls. Besides, liver needle biopsy and PBMC samples were taken from 5 patients infected with $\mathrm{HBV}$ but with negative detection of anti-HCV antibodies and serum HCVRNA. Moreover, PBMC samples from 5 healthy volunteers were used as negative controls. At least 2500 cells per sample were counted to obtain the percentage of positive cells.

PBMC were prepared by Ficoll-Hypaque (Lymphoprep) (Pharmacia, Uppsala, Sweden) gradient centrifugation, washed five times with $20 \mathrm{~mL}$ of phosphate-buffered saline (PBS) and then counted using a hemocytometer.

Antibodies and primers: The following mouse monoclonal antibodies (mAbs) were used for immunodetection studies: anti-HCcAg SS-HepC.1 mAb recognizing aa 5 to 35 of $\mathrm{HCcAg}$, anti-E1 SS-HepC. 2 mAb recognizing aa 190 to 219 of E1 and anti-E2 SSHepC. 3 mAb recognizing aa 643 to 671 of E2. These $\mathrm{mAbs}$ have been described elsewhere ${ }^{[16]}$.

The following synthetic probes corresponding to the highly conserved 5' noncoding region of HCV were used in this work:

* To detect the HCV-RNA of positive strand the biotin-labeled antisense probe (HCV-1) (5'- biotinGTTTATCCAAGAAAGGACCC-3', position 188207) was used.

* To detect the HCV-RNA of negative strand the biotin-labeled sense probe (HCV-2) (5'-biotinTTCACGCAGAAAGCGTCTAG-3', position 6382) was used.

For controls, an antisense biotin-labeled probe for rat prolactin mRNA (5'-biotinACATATCTGTATACAGGGTAG-3', position 63-82) was used.

These probes were synthesized and purified using conditions previously described ${ }^{[17]}$.

In situ hybridization (ISH) assay: Samples were immediately fixed with $4 \%$ paraformaldehyde in PBS at $4^{\circ} \mathrm{C}$ and then mounted on gelatine-coated glass slides and stored for 2 days at $-200{ }^{\circ} \mathrm{C}$. The ISH assay was performed as recently described ${ }^{[18]}$. The specificity of the ISH reaction was confirmed using experiments that involved: A-) hybridization of a section from the same liver biopsy or PBMC sample with a biotin-labeled probe having a sequence unrelated to HCV-RNA; B-) predigestion of biopsy sections or PBMC samples from patients showing positive detection of HCV-RNA in these samples with RNase A $\left(0.2 \mathrm{mg} \mathrm{mL}^{-1}\right)$ for $2 \mathrm{~h}$ at $37^{\circ} \mathrm{C}$ before hybridization; C-) hybridization with the probes specific for HCV-RNA to either liver biopsy sections or PBMC samples obtained from HCVuninfected individuals.

Immunofluorescence staining: Samples were immediately fixed with $4 \%$ paraformaldehyde in PBS at $4{ }^{\circ} \mathrm{C}$ and then mounted on gelatine-coated glass slides and stored for 2 days at $-200^{\circ} \mathrm{C}$. Later on, mounted samples were hydrated for $10 \mathrm{~min}$ in PBS and incubated with $0.2 \%$ Triton $\mathrm{X}$ in PBS during 10 min. 
To block non-specific antibody reaction, best results were obtained by incubating the sections with $0.2 \%$ bovine serum albumin (BSA) (free of $\mathrm{IgG}$ ) (Sigma Chemical Co. St. Louis, Mo.USA), for $10 \mathrm{~min}$ at RT. After two washes in PBS-T, samples were incubated overnight at $4{ }^{\circ} \mathrm{C}$ with either the anti-HCcAg mAb or the anti-E1 $\mathrm{mAb}$ or the anti-E2 mAb (dilutions 1:20 in PBS-T). Incubations were followed by washes with PBS-T. The second incubations were accomplished with FITC-conjugated anti-mouse IgG (dilutions 1:60 in PBS-T, Vector laboratories, Inc., Burlingame, CA., USA) for $1 \mathrm{~h}$ at RT. After three washes with PBS-T the sections from all samples were counterstained with propidium iodide (dilution 1:1000, Vector laboratories, Inc. Burlingame CA., USA), followed by extensive washing in PBS-T. Immunostained samples were coverslipped in Vectashield mountaing medium (Vector Laboratories, Inc. Burlingame, CA., USA), sealed with nail polish and viewed on a confocal laser scanning microscope. Negative controls were performed by substituting the primary antibodies with normal mouse serum.

Laser confocal scanning imaging and serial section collection: Samples were viewed with a 60x (NA 1.4) objective on a Nikon microscope with attached laser confocal scanning system MRC 600 (BioRad, Watfod). Ten to twelve fields were imaged from each sample. Four to fifteen serial optical z-sections $(0.2-0.5 \mu \mathrm{m}$ thick) were collected from each observed field using the dual channel imaging with filter $(554 \mathrm{~nm})$ for propidium iodide excitation and the filter $(494 \mathrm{~nm})$ for the fluorescein channel. Each series of confocal optical sections was scanned through a total of $25 \mu \mathrm{m}$. The resulting optical sections were fully projected onto twodimensional planes using the imaging processing system of the microscope (Camos package).

Statistical analysis: Data analysis was performed using GraphPad PRISM 4.0 software. Normality and homocedasticity of continuous variables were tested by the Komolgorov-Smirnov and Levene's tests, respectively. The mean was compared with the Student's t. $\quad \mathrm{p}<0.05$ was considered statistically significant.

\section{RESULTS}

Detection of HCV-RNA in liver biopsy samples: ISH analysis of liver biopsies from 3 chronically HCVinfected patients used as positive controls showed both positive and negative strands of the $\mathrm{HCV}$ genome localized in the cytoplasm of hepatocytes (Fig. 1A,B, Table 1). However, no hybridization signals were observed in liver biopsy specimens from negative control subjects (Fig. 1C). The specificity of the ISH reaction for HCV-RNA was confirmed by the failure to detect a positive signal when either an unrelated probe was used (Fig. 1D) or when the biopsy sections from $\mathrm{HCV}$-infected patients were predigested with RNase A before hybridization with $\mathrm{HCV}-1$ and $\mathrm{HCV}-2$ probes (Fig. 1E,F).

In addition, liver biopsies from 25 patients positive for anti-HCV antibodies and negative for serum HCVRNA were studied by ISH. The HCV-RNA of positive polarity was detected in the biopsy specimens from 23 out of 25 samples analyzed (92\%) (Tabla 1, Fig. 2A). However, no hybridization signals were observed in the biopsy specimens from the negative control subjects (Fig. 2B). The HCV-RNA of negative polarity was detected in the biopsy specimens from 21 out of 25 patients analyzed (84\%), whereas no hybridization signals were observed in the biopsy specimens from the negative control subjects (Tabla 1, Fig. 2C,D). Note that hybridization signals were localized in the cytoplasm of hepatocytes.

Hepatocytes containing hybridization signals were randomly distributed throughout the liver biopsy sections. The proportion of cells expressing the negative strand (mean $\pm \mathrm{SD}, 10.25 \% \pm 5.56 \%$ ) was lower than those expressing positive strand (mean \pm $\mathrm{SD}, 19.88 \% \pm 9.19 \%)(\mathrm{p}=0.0076$; Student's t test $)$.

Detection of HCV antigens in liver biopsy samples: Reaction products suggestive of $\mathrm{HCV}$ antigens within hepatocytes were observed (Table1, Fig. 3A-C). No hybridization signals were observed in the liver biopsy specimens from the control subjects (Fig. 3D). The specific stain reaction was blocked completely by incubation with normal mouse serum as primary antibodies (not shown). Hepatocytes containing such reaction products were distributed sporadically or focally in some lobuli.

Samples immunolabeled with anti-HCcAg, anti-E1 and anti-E2 mAbs showed perinuclear and also cytoplasmic reactions (Fig. 3A-C). In addition, $\mathrm{HCcAg}$ was immunolabeled both in the cytoplasm and nucleus in some hepatocytes (Not shown).

Detection of HCV-RNA in PBMC samples: The presence of HCV-RNA of both positive and negative polarity was investigated in PBMC samples obtained on the same day of the liver biopsy. 17 patients positive for anti-HCV antibodies and negative for serum HCVRNA were studied. In addition, 3 chronically HCVinfected patients testing positive for serum HCV-RNA were included as positive controls (Table 1).

Results obtained by ISH showed that the 3 patients who were included as positive controls had HCV-RNA of both polarities in their PBMC (Tabla 1, Fig. 4A,B). In contrast, PBMC from 5 healthy donors and from 5 HBV-infected patients were negative (Fig. 4C). The specificity of the ISH reaction for HCV-RNA of both polarities was confirmed by the failure to detect a 
Table 1: Clinical, virologic and histologic features in patients

\begin{tabular}{|c|c|c|c|c|c|c|c|c|c|c|c|c|c|c|}
\hline $\mathrm{P}$ & $\begin{array}{l}\mathrm{HCV} \\
\text { Antibody } \\
\text { Serum status }\end{array}$ & $\begin{array}{l}\text { HCV RNA } \\
\text { Serum } \\
\text { status }\end{array}$ & Age & Gender & $\begin{array}{l}\text { Treat } \\
\text { ment }\end{array}$ & $\begin{array}{l}\text { ALT/ } \\
\text { GGTP }\end{array}$ & Hist & $\begin{array}{l}\text { HCV } \\
\text { RNA } \\
\text { +Liver }\end{array}$ & $\begin{array}{l}\text { HCV } \\
\text { RNA } \\
\text { - Liver }\end{array}$ & $\begin{array}{l}\text { HCV } \\
\text { RNA } \\
+ \text { PBMC }\end{array}$ & $\begin{array}{l}\text { HCV } \\
\text { RNA - } \\
\text { PBMC }\end{array}$ & C & E1 & E2 \\
\hline 1 & + & + & 34 & $M$ & + & + & + & + & + & + & + & + & + & + \\
\hline 2 & + & + & 24 & $\mathrm{M}$ & + & + & + & + & + & + & + & + & + & + \\
\hline 3 & + & + & 74 & $\mathrm{M}$ & - & + & - & + & + & + & + & + & + & + \\
\hline 4 & + & - & 25 & M & - & + & - & + & + & nd & nd & - & + & - \\
\hline 5 & + & - & 35 & $\mathrm{~F}$ & - & - & - & + & + & nd & nd & - & + & + \\
\hline 6 & + & - & 33 & $\mathrm{~F}$ & - & - & - & - & - & nd & nd & + & + & - \\
\hline 7 & + & - & 30 & $\mathrm{~F}$ & - & - & - & + & + & nd & nd & - & - & + \\
\hline 8 & + & - & 62 & $\mathrm{M}$ & - & + & - & + & + & nd & nd & + & - & - \\
\hline 9 & + & - & 25 & $\mathrm{M}$ & + & - & + & + & + & nd & nd & + & - & - \\
\hline 10 & + & - & 53 & $\mathrm{~F}$ & - & - & + & + & + & nd & nd & + & + & + \\
\hline 11 & + & - & 23 & $\mathrm{M}$ & - & - & - & + & + & nd & nd & + & + & + \\
\hline 12 & + & - & 28 & $\mathrm{~F}$ & - & - & + & + & + & + & + & nd & nd & nd \\
\hline 13 & + & - & 32 & F & - & + & - & + & + & + & + & nd & nd & nd \\
\hline 14 & + & - & 34 & M & - & - & - & + & + & + & - & nd & nd & nd \\
\hline 15 & + & - & 46 & $\mathrm{M}$ & + & + & - & + & + & + & + & nd & nd & nd \\
\hline 16 & + & - & 42 & $\mathrm{M}$ & + & + & - & + & + & + & + & $\mathrm{nd}$ & nd & nd \\
\hline 17 & + & - & 55 & $\mathrm{~F}$ & - & - & - & + & + & + & + & nd & nd & nd \\
\hline 18 & + & - & 36 & $\mathrm{~F}$ & - & - & + & + & + & + & + & nd & nd & nd \\
\hline 19 & + & - & 39 & $\mathrm{M}$ & - & - & - & + & - & + & + & nd & nd & nd \\
\hline 20 & + & - & 36 & M & - & - & + & + & - & + & + & nd & nd & nd \\
\hline 21 & + & - & 48 & $\mathrm{~F}$ & + & - & - & + & + & + & + & nd & nd & nd \\
\hline 22 & + & - & 54 & $\mathrm{~F}$ & + & + & - & + & + & + & + & nd & nd & nd \\
\hline 23 & + & - & 55 & $\mathrm{~F}$ & + & + & + & - & - & - & - & nd & nd & nd \\
\hline 24 & + & - & 42 & $\mathrm{~F}$ & - & - & - & + & + & + & + & nd & nd & nd \\
\hline 25 & + & - & 33 & M & - & - & - & + & + & + & - & nd & nd & nd \\
\hline 26 & + & - & 66 & $\mathrm{~F}$ & - & - & - & + & + & + & + & nd & nd & nd \\
\hline 27 & + & - & 50 & M & - & - & - & + & + & + & + & nd & nd & nd \\
\hline 28 & + & - & 43 & M & - & - & - & + & + & + & + & nd & nd & nd \\
\hline
\end{tabular}

P: Patient; HCV RNA+: Detection of RNA of positive polarity; HCV RNA-: Detection of RNA of negative polarity; nd: not determined; +: Positive detection; -:Negative detection; Hist: Histological diagnoses, +: chronic hepatitis, -: no chronic hepatitis

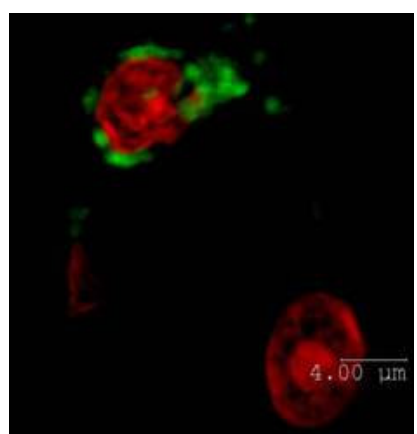

A

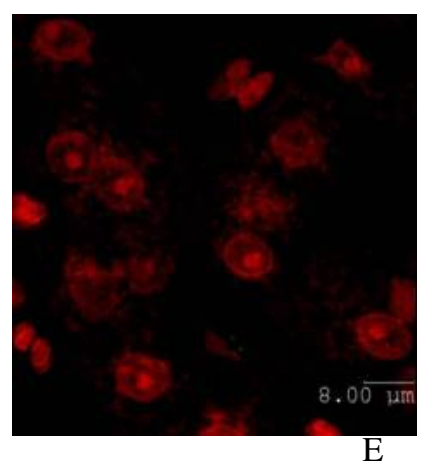

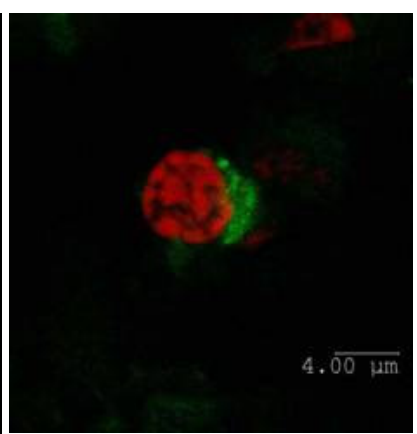

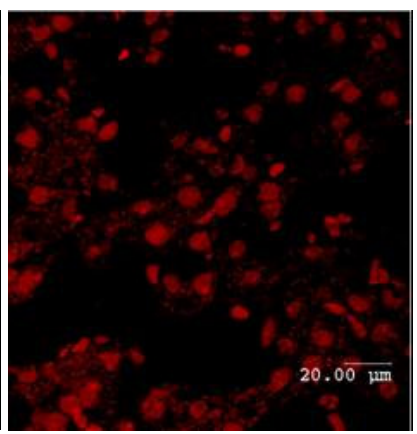

$\mathrm{C}$
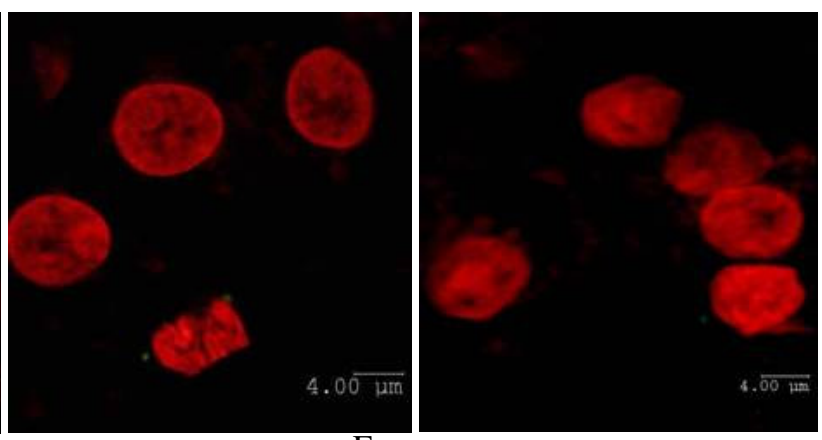

Fig. 1: Detection of HCV-RNA of positive polarity (A) and of negative polarity (B), in liver biopsy specimens from patients positive for HCV-RNA in serum. (C) Absence of hybridization signals in healthy donor liver biopsies. Other specificity controls are hybridization with an unrelated probe (D) and RNase A predigestion of biopsy sections from HCV-infected patients before hybridization with $\mathrm{HCV}-1$ (E) and HCV-2 (F) probes (Bar=4 $\mu \mathrm{m}$ in A,B,E and F; $8 \mu \mathrm{m}$ in D; $20 \mu \mathrm{m}$ in C) 

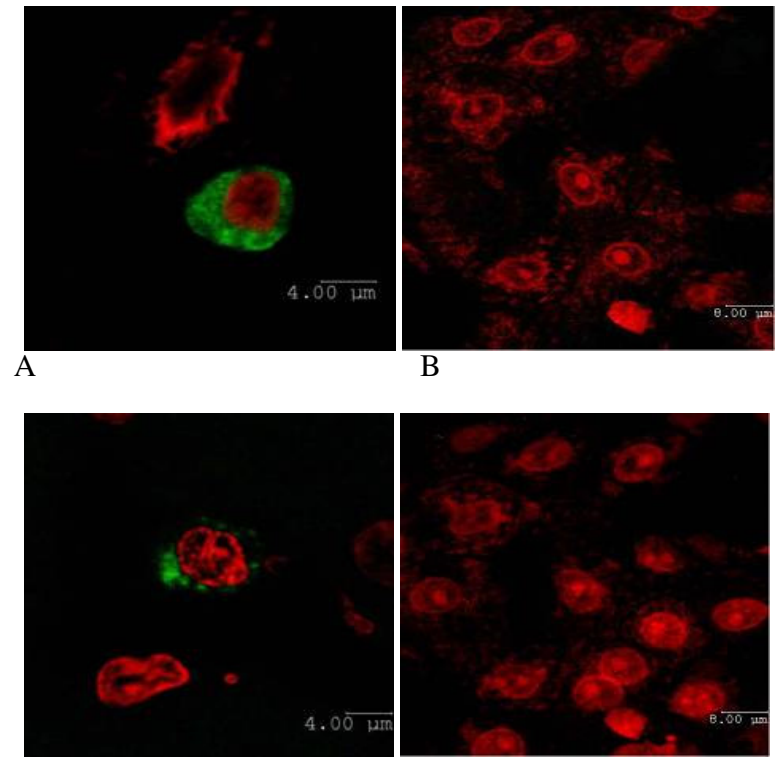

C

$\mathrm{D}$

positive signal when either an unrelated probe was used (Fig. 4D) or when PBMC samples from HCVinfected patients were predigested with RNase A before hybridization with $\mathrm{HCV}-1$ and $\mathrm{HCV}-2$ probes (Fig. 4E,F).

The HCV-RNA of positive polarity was detected in PBMC from 16 out of 17 samples analyzed (94\%) by ISH (Tabla 1, Fig. 5A). On the other hand, Tabla 1 illustrates that the HCV-RNA of negative polarity was detected in 14 out of 17 samples analyzed (82\%) (Tabla 1, Fig. 5C). No positive signals were observed in PBMC from the control subjects (Fig. 5B,D).

Positive hybridization signals were localized in the cytoplasm of PBMC and the proportion of cells expressing the negative strand (mean $\pm \mathrm{SD}, 14.58 \% \pm$ $5.45 \%$ ) did not significantly differed to those expressing positive strand (mean \pm SD, 14.03\% \pm $6.68 \%)(\mathrm{p}>0.05$; Student's t test).

\section{DISCUSSION}

Detection of HCV components in either the human liver or nonhepatic compartments such as PBMC is a useful tool in the determination of the pathogenesis of $\mathrm{HCV}$-associated diseases and in the selection of patients with HCV who may be suitable candidates for treatment. Although the exact mechanism of $\mathrm{HCV}$ replication is still not fully known, there is some evidence indicating that the virus replicates through synthesis of a complementary negative-strand RNA intermediate (anti-genomic strand). Thus, the detection of negative HCV-RNA strand can be regarded as a marker of ongoing viral replication ${ }^{[19-24]}$.

In this study, both positive and negative HCVRNA strands were detected in liver biopsies from patients positive for anti-HCV antibodies and negative for serum HCV-RNA using an ISH assay. Similarly, previous studies have demonstrated the presence of positive and negative HCV-RNA strands in hepatocytes from patients with chronic $\mathrm{HCV}$-infection and with occult HCV-infection by $\operatorname{ISH}^{[19,20,25]}$.

The hybridization signals were detected in the cytoplasm of hepatocytes. Most studies reported the detection of HCV-RNA in the cytoplasm of hepatocytes $^{[25]}$. However, the presence of specific nuclear and perinuclear signals in addition to the signal in cytoplasm has been reported ${ }^{[26,27]}$. Results from this work support previous studies suggesting that the cytoplasm is the place of active HCV replication.

The finding that there were a lower proportion of cells expressing the anti-genomic strand than those expressing the positive strand is in agreement with quantitative analysis of the relative amount of the minus-strand of HCV-RNA which indicates that it can be 10 to 100 times lower than that of the plus one in liver tissue of patients with chronic hepatitis ${ }^{[28]}$. 


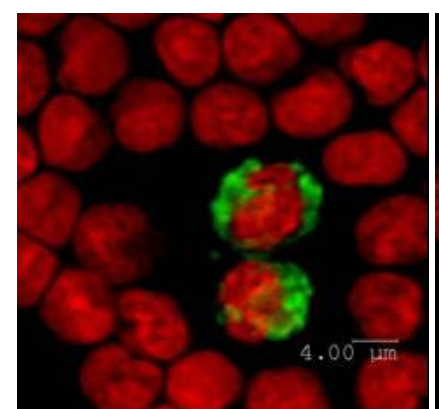

A

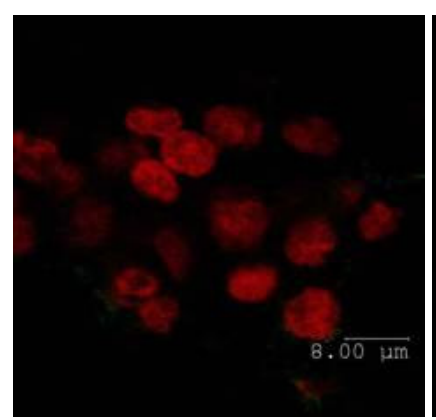

$\mathrm{D}$

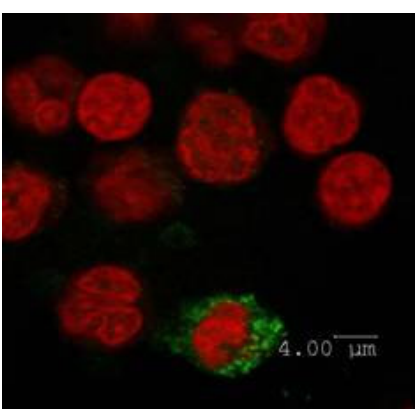

B

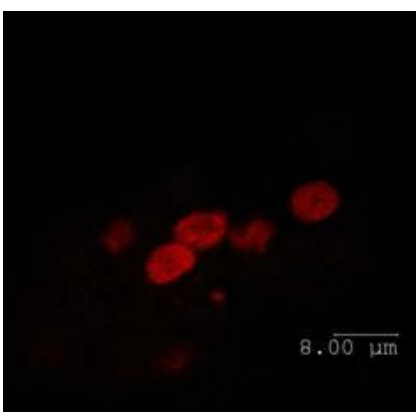

$\mathrm{E}$

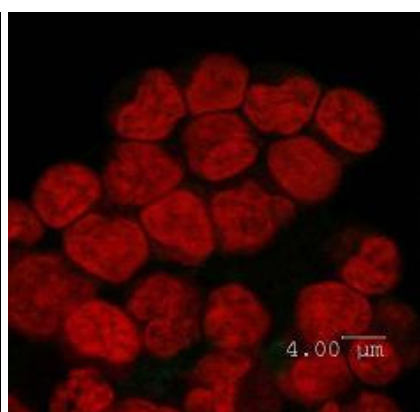

$\mathrm{C}$

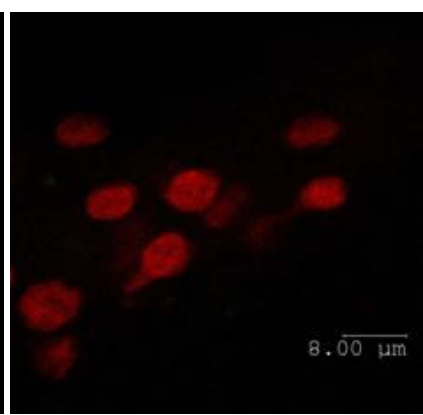

$\mathrm{F}$

Fig. 4: Detection of HCV-RNA of positive polarity (A) and HCV-RNA of negative polarity (B), in PBMC from patients positive for HCV-RNA in serum. (C) Absence of hybridization signals in PBMC from healthy donor liver biopsies. Other specificity controls are hybridization with an unrelated probe (D) and RNase A predigestion of PBMC from HCV-infected patients before hybridization with HCV-1 (E) and HCV-2 (F) probes (Bar $=4 \mu \mathrm{m}$ in $\mathrm{A}-\mathrm{C} ; 8 \mu \mathrm{m}$ in $\mathrm{D}-\mathrm{F}$ )
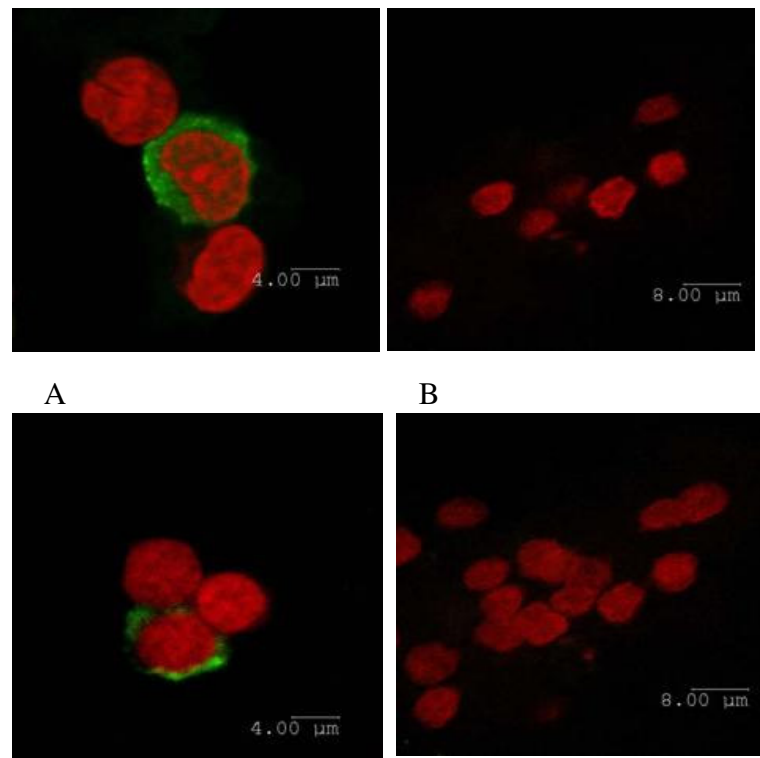

$\mathrm{C}$
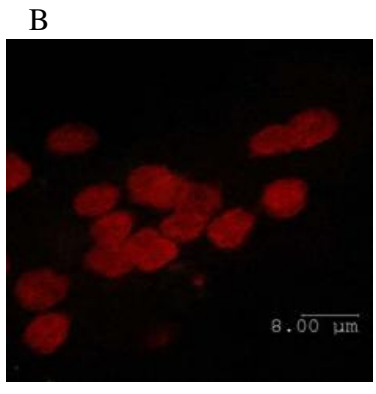

$\mathrm{D}$

Fig. 5: Detection of HCV-RNA of either positive (A) or negative $(\mathrm{C})$ polarity in $\mathrm{PBMC}$ from patients positive for anti-HCV antibodies and negative for serum HCVRNA. (B,D) Absence of hybridization signals in PBMC from healthy donor liver biopsies using either $\mathrm{HCV}-1$ (B) or HCV-2 (D) probes (Bar=4 $\mu \mathrm{m}$ in A,C; 8 $\mu \mathrm{m}$ in $\mathrm{B}, \mathrm{D})$
In addition, it is interesting to note that the frequency of hepatocytes displaying HCV-RNA in these patients is lower than that reported for patients with chronic hepatitis $C^{[29,30]}$ but higher than that reported for patients with occult HCV infection ${ }^{[25]}$.

It is known that expression of viral proteins is essential for $\mathrm{HCV}$ replication. Thus, detection of $\mathrm{HCV}$ structural proteins in hepatocytes provides further evidences of HCV replication in these cells. Immunofluorescence showed a predominantly cytoplasmic localization of HCV proteins, supporting the findings using the ISH assay. However, as HCcAg also localized in the nucleus of some hepatocytes a nuclear phase of the viral replicative cycles can not be ruled out ${ }^{[9,31-33]}$.

Data shown here indicate that a high proportion of $\mathrm{HCV}$-infected patients harbour specific viral sequences in PBMC. This extrahepatic HCV infection may be active, as documented by the presence of viral antigenomic RNA in PBMC. Our results confirm previous observations indicating that $\mathrm{HCV}$ can infect PBMC $^{[10,25,34-36]}$. Some studies have shown both genomic and anti-genomic forms of HCV-RNA in isolated peripheral blood lymphocytes ${ }^{[25,37]}$. In addition, HCV-RNA positive and negative strands have been detected in PBMC from chronically infected patients and in PBMC from patients with occult $\mathrm{HCV}$ 
infection $^{[10,34-36]}$. Moreover, it has been shown that $\mathrm{HCV}$ may persist in the liver and PBMC after spontaneous or treatment-induced resolution of hepatitis $C^{[35,36]}$.

In contrast to that observed in the liver biopsies of these patients, the proportion of PBMC containing the HCV-RNA negative strand did not significantly differed to those containing the HCV-RNA of positive strand. Similarly, a recent study showed a significant correlation between the percentages of PBMC with the HCV-RNA positive strand and that of PBMC with the $\mathrm{HCV}-\mathrm{RNA}$ negative strand in patients with occult $\mathrm{HCV}$ infection $^{[34]}$. However, the frequency of PBMC displaying HCV-RNA found in this study is higher than that reported for patients with occult HCV infection ${ }^{[34]}$. Occult HCV-infection is defined by the presence of HCV-RNA in the liver in the absence of anti-HCV and serum HCV-RNA ${ }^{[25]}$. The presence of a higher frequency of hepatocytes and PBMC displaying HCVRNA in patients positive for anti-HCV antibodies and negative for serum HCV-RNA than that observed in patients with occult $\mathrm{HCV}$-infection may explain the induction of detectable anti-HCV antibodies in these patients.

The main site of infection for $\mathrm{HCV}$ is the liver. This hepatotropism leads to the development of liver injury that can be monitored by measurement of the levels of serum aminotransferases. However, 12 out of 13 patients with clinical and histological resolution of hepatitis, with sustained normalization of biochemical indicators of liver function test and clearance of HCV RNA from serum, (as determined by conventional laboratory assays) contained HCV-RNA in either liver or PBMC. This is in agreement with recent findings showing that HCV-RNA can persist at very low levels in the serum, PBMC and liver for many years after spontaneous or antiviral therapy induced clearance of serum viral RNA and normalization of transaminases ${ }^{[35,36]}$. So, this work provides further evidences that the intermediate replicative form of the $\mathrm{HCV}$ genome can persist in hepatocytes and PBMC after apparently complete resolution of chronic hepatitis C.

\section{ACKNOWLEDMENTS}

The authors thank Jesus Seone and Nilda Tamayo for their excellent technical assistance, and Dr. Rafael F. Sanchez-Betancourt for critical reading of the manuscript and for many helpful suggestions.

\section{REFERENCES}

1. Choo,Q.L., G. Kuo, A.J. Weiner, L.R. Overby, D.W. Bradley and M. Houghton,. 1989. Isolation of a cDNA clone derived from a blood-borne nonA, non-B viral hepatitis genome. Science, 244: 359-362.
2. Leone, N. and M. Rizzetto, 2005. Natural history of hepatitis $\mathrm{C}$ virus infection: From chronic hepatitis to cirrhosis, to hepatocellular carcinoma. Minerva Gastroenterol. Dietol., 51: 31-46.

3. Op, D.B., L. Cocquerel and J. Dubuisson, 2001. Biogenesis of hepatitis $\mathrm{C}$ virus envelope glycoproteins. J. Gen. Virol., 82: 2589-2595.

4. Grakoui, A., C. Wychowski, C. Lin, S.M. Feinstone and C.M. Rice, 1993. Expression and identification of hepatitis $\mathrm{C}$ virus polyprotein cleavage products. J. Virol., 67: 1385-1395.

5. Hijikata, M., N. Kato, Y. Ootsuyama, M. Nakagawa and K. Shimotohno, 1991. Gene mapping of the putative structural region of the hepatitis $\mathrm{C}$ virus genome by in vitro processing analysis. Proc. Natl. Acad. Sci. U.S.A., 88: 55475551.

6. Pawlotsky, J.M., 1999. Diagnostic tests for hepatitis C. J. Hepatol., 31: 71-79.

7. Komminoth, P., V. Adams, A.A. Long, J. Roth, P. Saremaslani, R. Flury, M. Schmid and P.U. Heitz, 1994. Evaluation of methods for hepatitis $\mathrm{C}$ virus detection in archival liver biopsies. Comparison of histology, immunohistochemistry, in-situ hybridization, reverse transcriptase polymerase chain reaction (RT-PCR) and in situ RT-PCR. Pathol. Res. Pract., 190: 1017-1025.

8. Sansonno, D., V. Cornacchiulo, A.R. Iacobelli, P. Gatti, M. Di Stasi and F. Dammacco, 1995. Demonstration and distribution of HCV RNA sequences by in situ hybridization and HCVrelated proteins by immunohistochemistry in the liver tissue of patients with chronic HCV infection. Pathobiology, 63: 239-248.

9. Walker, F.M., M.C. Dazza, M.C. Dauge, O. Boucher, C. Bedel, D. Henin and T. Lehy, 1998. Detection and localization by in situ molecular biology techniques and immunohistochemistry of hepatitis $\mathrm{C}$ virus in livers of chronically infected patients. J. Histochem. Cytochem., 46: 653-660.

10. Haydon, G.H., L.M. Jarvis, C.S. Blair, P. Simmonds, D.J. Harrison, K.J. Simpson and P.C. Hayes, 1998. Clinical significance of intrahepatic hepatitis $\mathrm{C}$ virus levels in patients with chronic HCV infection. Gut, 42: 570-575.

11. Bonacini, M. and A.G. Redeker, 1999. Intrahepatic HCV levels in chronic HCV infection. Gut, 45: 630-631.

12. McGuinness, P.H., G.A. Bishop, D.M. Painter, R. Chan and G.W. McCaughan, 1996. Intrahepatic hepatitis C RNA levels do not correlate with degree of liver injury in patients with chronic hepatitis C. Hepatology, 23: 676-687.

13. Basaras, M., H.B. de las, B.M. Garcia, L. Gallego, E. Arrese and R.Cisterna, 1996. Detection of hepatitis $\mathrm{C}$ virus RNA in serum and peripheral blood mononuclear cells in patients with chronic hepatitis $\mathrm{C}$ treated with interferon alpha. Eur. J. Clin. Microbiol. Infect. Dis., 15: 887-890. 
14. Manzin, A., M. Candela, S. Paolucci, M.L. Caniglia, A. Gabrielli and M. Clementi, 1994. Presence of hepatitis $\mathrm{C}$ virus (HCV) genomic RNA and viral replicative intermediates in bone marrow and peripheral blood mononuclear cells from HCV-infected patients. Clin. Diagn. Lab Immunol., 1: 160-163.

15. Mazur, W., U. Mazurek, M. Jurzak, T. Wilczok, Z. Bulanowski and Z. Gonciarz, 2001. Positive and negative strands of HCV-RNA in sera and peripheral blood mononuclear cells of chronically hemodialyzed patients. Med. Sci. Monit., 7: 108-115.

16. Falcon, V., N. Acosta-Rivero, G. Chinea, J. Gavilondo, M.C. de la Rosa, I. Menendez, S. Duenas-Carrera, A. Vina, W. Garcia, B. Gra, M. Noa, E. Reytor, M.T. Barcelo, F. Alvarez and J. Morales-Grillo, 2003. Ultrastructural evidences of $\mathrm{HCV}$ infection in hepatocytes of chronically HCVinfected patients. Biochem. Biophys. Res. Commun., 305: 1085-1090.

17. Pon, R.T. and S. Yu. 2004. Linker phosphoramidite reagents for the attachment of the first nucleoside to underivatized solid-phase supports. Nucleic Acids Res., 32: 623-631.

18. Falcón, V., N. Acosta-Rivero, M. Shibayama, J. Luna-Munoz, M. Miranda-Sanchez, J. Gavilondo, M.C. de la Rosa, I. Menéndez, B. Gra, W. García, S. Dueñas-Carrera, J. Silva, G. Chinea, M. González-Bravo, F. Alvarez, J. Morales, J. Kouri and V. Tsutsumi, 2005. Detection of HCV components and pathological reactions in apoptotic hepatocytes from chronically $\mathrm{HCV}$-infected patients. Am. J. Infec. Diseases, 1: 12-24.

19. Gastaldi, M., A. Massacrier, R. Planells, A. Robaglia-Schlupp, I. Portal-Bartolomei, M. Bourliere, F. Quilici, J. Fiteni, E. Mazzella and P. Cau, 1995. Detection by in situ hybridization of hepatitis $\mathrm{C}$ virus positive and negative RNA strands using digoxigenin-labeled cRNA probes in human liver cells. J. Hepatol., 23: 509-518.

20. Lau, J.Y., K. Krawczynski, F. Negro and R.P. Gonzalez-Peralta, 1996. In situ detection of hepatitis C virus--a critical appraisal. J. Hepatol., 24: 43-51.

21. Lerat, H., F. Berby, M.A. Trabaud, O. Vidalin, M. Major, C. Trepo and G. Inchauspe, 1996. Specific detection of hepatitis $\mathrm{C}$ virus minus strand RNA in hematopoietic cells. J. Clin. Invest., 97: 845-851.

22. Negro, F., D. Pacchioni, Y. Shimizu, R.H. Miller, G. Bussolati, R.H. Purcell and F. Bonino, 1992. Detection of intrahepatic replication of hepatitis $\mathrm{C}$ virus RNA by in situ hybridization and comparison with histopathology. Proc. Natl. Acad. Sci. U.S.A., 89: 2247-2251.
23. Ohishi, M., S. Sakisaka, M. Harada, H. Koga, E. Taniguchi, T. Kawaguchi, K. Sasatomi, M. Sata, T. Kurohiji and K. Tanikawa, 1999. Detection of hepatitis- $\mathrm{C}$ virus and hepatitis- $\mathrm{C}$ virus replication in hepatocellular carcinoma by in situ hybridization. Scand. J. Gastroenterol., 34: 432438.

24. Scheuer, P.J., K. Krawczynski and A.P. Dhillon, 1997. Histopathology and detection of hepatitis C virus in liver. Springer Semin. Immunopathol., 19: 27-45.

25. Castillo, I., M. Pardo, J. Bartolome, N. OrtizMovilla, E. Rodriguez-Inigo, S. de Lucas, C. Salas, J.A. Jimenez-Heffernan, A. Perez-Mota, J. Graus, J.M. Lopez-Alcorocho and V. Carreno, 2004. Occult hepatitis $\mathrm{C}$ virus infection in patients in whom the etiology of persistently abnormal results of liver-function tests is unknown. J. Infect. Dis., 189: 7-14.

26. Nouri Aria, K.T., R. Sallie, D. Sangar, G.J. Alexander, H. Smith, J. Byrne, B. Portmann, A.L. Eddleston and R. Williams, 1993. Detection of genomic and intermediate replicative strands of hepatitis $\mathrm{C}$ virus in liver tissue by in situ hybridization. J. Clin. Invest., 91: 2226-2234.

27. Nuovo, G.J., K. Lidonnici, P. MacConnell and B. Lane, 1993. Intracellular localization of polymerase chain reaction (PCR)-amplified hepatitis C cDNA. Am. J. Surg. Pathol., 17: 683690.

28. Fong, T.L., M. Shindo, S.M. Feinstone, J.H. Hoofnagle and A.M. Di Bisceglie, 1991. Detection of replicative intermediates of hepatitis $\mathrm{C}$ viral RNA in liver and serum of patients with chronic hepatitis C. J. Clin. Invest., 88: 1058-1060.

29. Agnello, V., G. Abel, G.B. Knight and E. Muchmore, 1998. Detection of widespread hepatocyte infection in chronic hepatitis $\mathrm{C}$. Hepatology, 28: 573-584.

30. Gosalvez, J., E. Rodriguez-Inigo, J.L. RamiroDiaz, J. Bartolome, J.F. Tomas, H. Oliva and V. Carreno, 1998. Relative quantification and mapping of hepatitis $\mathrm{C}$ virus by in situ hybridization and digital image analysis. Hepatology, 27: 1428-1434.

31. Acosta-Rivero, N., V. Falcon, C. Alvarez, A. Musacchio, G. Chinea, d.l.R. Cristina, A. Rodriguez, S. Duenas-Carrera, V. Tsutsumi, M. Shibayama, I. Menendez, J. Luna-Munoz, M.M. Miranda-Sanchez, J. Kouri and J. Morales-Grillo, 2003. Structured HCV nucleocapsids composed of P21 core protein assemble primary in the nucleus of Pichia pastoris yeast. Biochem. Biophys. Res. Commun., 310: 48-53. 
32. Falcon, V., N. Acosta-Rivero, G. Chinea, M.C. de la Rosa, I. Menendez, S. Duenas-Carrera, B. Gra, A. Rodriguez, V. Tsutsumi, M. Shibayama, J. Luna-Munoz, M. M. Miranda-Sanchez, J. MoralesGrillo and J. Kouri, 2003. Nuclear localization of nucleocapsid-like particles and $\mathrm{HCV}$ core protein in hepatocytes of a chronically $\mathrm{HCV}$-infected patient. Biochem. Biophys. Res. Commun., 310: 54-58.

33. Falcon, V., N. Acosta-Rivero, M. Shibayama, G. Chinea, J.V. Gavilondo, M.C. de la Rosa, I. Menendez, B. Gra, S. Duenas-Carrera, A. Vina, W. Garcia, M. Gonzalez-Bravo, J. Luna-Munoz, M. Miranda-Sanchez, J. Morales-Grillo, J. Kouri and V. Tsutsumi, 2005. HCV core protein localizes in the nuclei of nonparenchymal liver cells from chronically HCV-infected patients. Biochem. Biophys. Res. Commun., 329: 1320-1328.

34. Castillo, I., E. Rodriguez-Inigo, J. Bartolome, S. de Lucas, N. Ortiz-Movilla, J.M. Lopez-Alcorocho, M. Pardo and V. Carreno. 2005. Hepatitis C virus replicates in peripheral blood mononuclear cells of patients with occult hepatitis $\mathrm{C}$ virus infection. Gut, 54: 682-685.
35. Pham, T.N., S.A. MacParland, P.M. Mulrooney, H. Cooksley, N.V. Naoumov and T.I. Michalak, 2004. Hepatitis $\mathrm{C}$ virus persistence after spontaneous or treatment-induced resolution of hepatitis C. J. Virol., 78: 5867-5874.

36. Radkowski, M., J.F. Gallegos-Orozco, J. Jablonska, T.V. Colby, B. Walewska-Zielecka, J. Kubicka, J. Wilkinson, D. Adair, J. Rakela and T. Laskus, 2005. Persistence of hepatitis $\mathrm{C}$ virus in patients successfully treated for chronic hepatitis $\mathrm{C}$. Hepatology, 41: 106-114.

37. Felgar, R.E., K.T. Montone and E.E. Furth, 1996. A rapid method for the detection of hepatitis $C$ virus RNA by in situ hybridization. Mod. Pathol., 9: 696-702. 